\title{
Route Choice: Higher Vocational Education to Further Development in China
}

\author{
Junli Jia ${ }^{1}$, Zhaohui Yang ${ }^{2}$ \\ ${ }^{1}$ President Office, Hebei College of Industry and Technology, Shijiazhuang City, China \\ ${ }^{2}$ Department of Scientific and Research, Hebei College of Industry and Technology, Shijiazhuang City, China
}

\section{Email address:}

372563766@qq.com (Zhaohui Yang)

\section{To cite this article:}

Junli Jia, Zhaohui Yang. Route Choice: Higher Vocational Education to Further Development in China. Education Journal. Vol. 4, No. 6, 2015, pp. 352-355. doi: 10.11648/j.edu.20150406.15

\begin{abstract}
There are two levels of higher education in China: one is higher education institutes, consists of junior colleges, four-year colleges and comprehensive universities. The other one is higher vocational education institutes, consists of higher vocational colleges only, that is to say, the student studying in that ones cannot get the bachelor certification. But with the development of Chinese economy and living standard, the companies need higher skilled talents cultivated. Except for employment, the students long for continuing education. However, they found there was no way to choose when they graduated from the higher vocational colleges. They must enroll four-year colleges to get bachelor degree, not certification, which were not suitable to their learned knowledge. In China, there are two different kinds of higher education, either professional or academic. However there is no higher diploma for students in higher vocational education. It is necessary to build the higher vocational education system including junior colleges, four-year level colleges and graduate level colleges. Here we discuss the route choice including education objective, teaching mode, curriculum, practical exercise and setting standard.
\end{abstract}

Keywords: Route Choice, Higher Vocational Education, Four-Year Level College, Setting Standard

\section{Introduction}

There have been 2529 institutes in Chinese higher education by the year 2014, which consist of 1202 four-year colleges, 1327 higher vocational colleges. [1] Students in these colleges are total 25.47 million. Higher vocational college students are 8.03 million. One part of those students went into society, the other part of them need to improve their diploma. Junior college vocational education cannot meet the social needs Base on situation, higher vocational education should be added the four-year college vocational education, graduate vocational education in it.

With the view of global vocational education, Germany had built fachhochs-chule(FH) and university of applied sciences since the 1970s, granted bachelor, diplom (cancelled), master The UK had built Polytechnic, college of higher education and tertiary college, granted higher-level National Vocational Qualifications (NVQs) respectively. Most colleges of technology in Japan were national institutions established to train highly skilled technicians in five-year programs in a number of fields, including the merchant marine. Sixty-two technical colleges had been operating since the early 1960 s.
About $10 \%$ of college graduates transferred to universities as third-year students, and some universities, notably the university of Tokyo and the Tokyo institute of technology, earmarked entrance places for these transfer students since the 1980s. More Australian technical and further education colleges are awarding degrees despite strong opposition from the country's vice-chancellors. The sector enrolls more than 1 million students on apprenticeship and other vocational courses each year. But many colleges want to compete with universities by offering their own degrees. The Australian Vice-Chancellors' Committee believes that the higher education and vocational education sectors should be kept separate. Vice-chancellors have voiced opposition to colleges awarding associate or applied degrees. Colleges with degree courses include the Adelaide Institute of Technical and Further Education and the Canberra Institute of Technology. Both received authority from the respective state and territory governments to award degrees, as have several private vocational education institutions. Some technical colleges have signed agreements with universities to run degree programs for their own students. The universities accredit the courses, which are taught at the colleges, and issue the awards. 
Compared with the vocational system in main countries, there are essential differences between regular higher education and higher vocational education. Chinese higher vocational education has junior college, is not rational and incomplete. Regular higher education is taking the academic and theoretical models in the undergraduate level. Higher vocational education is defined as applied and skilled model. So two kinds of higher education can not be communication and convergence in curriculum, subject materials, teaching methods and so on. The difference is obvious between them. From 2005 onwards, higher vocational education students applied to regular higher education for further studies from $10 \%$ to $5 \%$. The declining is sudden and huge. However higher vocational education enrollment rating has a sharp rise in the number of students. Tey have to face the most urgent bottlenecks in the development of expanding and advancing space.

\section{Local Four-Year Colleges Transfer to Polytechnic College}

Local four-year colleges are that have been upgraded junior colleges since 1999. Those colleges implement academic courses not occupational courses. Let them transfer to polytechnic colleges facing the following dilemma.

\subsection{School Gradation}

Local four-year colleges wouldn't transfer to applied technology or vocational technology. Their concepts are that they are university, not vocational college. They upgraded according to provisional rules of ordinary undergraduate school setting by education department, which amended in 2006. Common sense in those colleges is academic courses and researches. There are no faculties and facilities for supporting practical teaching and training. They aimed at climb up for applying master or doctor degree conferral right. Some evidence suggests that opinion, such as there were 178 colleges applying for transferring, accounting for only one forth nationwide [2].

Specialties plan and talents cultivation mode in those colleges are old-timed, can not be matched the local economy development. Teaching objectives are set to theoretical and logic training, lacking practical training. Owing to some colleges would not open new specialties except for original ones. The second factor is owing to leadership, some colleges would try to conservation instead of creation, preventing from doing wrong things. The third factor is that they don't know how to transfer or what to transfer, existing psychological obstacle for setting vocational education back [3].

\subsection{Government Gradation}

The transformation of four-year colleges is oriented by local government. The colleges haven't higher autonomous right in operating schools. The policy limited the college's development, bachelor degree higher vocational education went forward lowly, and higher skilled talents were insufficiency. According to UN statistics, index of Chinese skilled labors accounted for No.59 in the world, higher skilled labors for $5 \%$, middle level skilled labors for $35 \%$, low skilled labors for $60 \%$, but developed countries are $35 \%, 50 \%$ and $15 \%$ respectively [4]. Lawmaking policies about higher vocational education are not enough. At present, legislations and regulations can not guarantee the higher vocational education system. Compared with Europe polytechnic institutes, they have rich and perfect institutions in the course of development. Government invested in these colleges in a small sum which can not afford the reform. Central government has not granted the colleges by so far. Polytechnics abroad which developed in the past had been granted a lot of money by countries [5].

\subsection{Society Gradation}

At present, the government and the higher vocational colleges have reached an agreement on the importance of school-enterprise cooperation, but enterprises are not so interested in it. From the view of resource dependence theory, the power of cooperation among organizations comes from resource dependence on each other. The empirical research shows that enterprises have certain dependency on human resources, technology resources, information resources, reputation resources and so on in the school-enterprise cooperation. But the enterprises are not positive in this aspect, except for tax preference.

Teaching mode decides talent cultivation specification, level and type. There is certain teaching mode; the talent cultivation will be alike. As a local four-year college, it must strive to construct the teaching mode of applied talent training, integrate the teaching and practice, transfer school-running mode. That is the necessary way for four-year colleges steering to vocational education [6].

\section{Higher Vocational Colleges Upgrade to Four-Year Colleges}

Higher vocational colleges have cultivated the main higher applied talents. With construction in the decade, a few higher vocational colleges have reached or surpassed general four-year colleges. At present, there are state-owned, joint-stock and private colleges in types. Some of these colleges have strong advantages of construction four-year vocational education, but lacking of setting standards. From national gradation, the department of education worried about them changing to academic colleges. So polices were issued which limited higher vocational colleges to transfer.

\subsection{Policy Confusion}

There is a set of setting standards for four-year colleges in China, which is suitable for academic colleges, such as Peking University, Tsinghua University and so on. There are no setting standards for higher vocational education. The main problem for upgrading higher vocational colleges is what kind of standard needs to be complied. In common sense, it is trend to upgrade means improving "hierarchy", gain more resources. 
If the educational administration blindly opens the grant for upgrading, higher vocational colleges would go to apply it. Facing 1200 Chinese higher vocational colleges, that would be disaster for higher education.

At present, there is a path to go to study bachelor degree course, but higher vocational students recruited by four-year colleges were very little. Taking Peking for example, educational administration regulated $15 \%$ graduates from higher vocational colleges which were permitted to apply, but practical admission amount was low percentage. Academic degree worshiped in China, the link between higher vocational colleges and four-year colleges was not built, which strengthened academic instead of vocational. It is the policy confusion for developing four-year vocational colleges [7].

\subsection{Theory Acquaintance}

About system of vocational education, Chinese vocational education circle has agreed with it consists of three levels which are junior college, four-year colleges and postgraduate. In 1980s, the scholars had recognized higher vocational education which should include four-year colleges. They proposed how to link vocational education among primary, middle and higher level, and how to link vocational education and academic education. That would make all kinds of students continue higher level study which encouraged students learning enthusiasm With vocational education development, more and more scholars advocated to build four-year colleges, and to build independent vocational education system.

\subsection{Reality Necessity}

It is the key moment to transform for industry, which needs higher skilled talents. Talents cultivation specification became diversity, skilled talents comprehensive quality became higher, skilled talents should have many jobs competence. The transformation is special that existing different levels of production modes, which embodied mass middle or even low level manufactures. From the view of market, primary and middle technical talents are needed. For example, 2012 Ningbo international talents summit forum showed that there were 741 jobs need in 22 fields, of which there were 297 jobs need including engineers, designers and technicians, accounted for $40.1 \%$, but the number was climbing. Therefore, primary, middle and high levels of vocational education added undergraduate, postgraduate vocational education would fit economy development [8].

\section{Path Choice: Four-Year Vocational Colleges Building}

From the view of internal education, we should meet higher vocational students to continue study so that promoted students themselves. From the view of external education, we should meet satisfaction of gray collar in companies. In nature, these problems are high skilled talents cultivation problems.

\subsection{Construction Customized System According to Local Vocational Education}

Vocational education is a type, not a level, not even limited to junior college. Vocational education development is the cause of social production increasing for skilled talents. With social production technology and employees skilled promoted, undergraduate or postgraduate levels of vocational education would be a necessity. Due to our unbalancing economy development in different region, skilled talents are needed differently. Vocational education should adjust to local economy development and education administration could have opened policies according to skilled talents need standard, customized system.

\subsection{Flexible School System in Higher Vocational Education Building}

Curricula in different higher vocational colleges are not same in development. If education administration blindly opens permission of upgrading, all curricula building to four-year school system are not correct or right. What we should do is to build certain curriculum for four-year school system according to industry development and skilled talents requirements. Choosing some strong advantages in running schools, faculties and reputations ally main industries in region to construct four-year vocational education talents cultivation. Trying to issue professional certification or diploma satisfied the students need and met high skilled talents demand [9].

\section{Conclusion}

Government and educational administrations play critical roles in shaping four-year higher vocational education institutions' behavior. The government is involved in almost every step of decision-making including funding and developing programs, hiring teachers, and setting student admission criteria. Higher vocational education colleges must request approval from government administration in order to set up new programs. National policy changes and related implemented procedures play a crucial role in vocational education development toward modernization and adaptation. The right process of management by multiple levels of governments ensures higher vocational colleges kept on track [10].

The leading export-oriented economic growth in labor-intensive industries has come to an end. Adjusting the economic structure and the transformation of economic growth mode are the most important measure to realize China's economy sustained, rapid, coordinated and healthy development. External relations showed that the education must adapt to social development. On one hand, education is constrained by socio-economic, political, cultural factors. On the other hand, education could promote social progress in social economic, political and cultural development. Changing economic structure is necessary for demanding education structure reform, what kind of economic structure 
will require a certain educational structure for matching, and education structure could react on economic structure. Reasonable education structure ensured the successful transformation in the economic structure. Transformation of the economic structure and industrial upgrading means China's labor intensive industries changed to capital and technology intensive industries. Capital intensive companies are characterized by technical equipment, large amount of investment, cash flow, investment. Technology-intensive industries (also known as knowledge-intensive industries) are characterized by its equipment, production processes based on advanced science and technology. It develops on the basis of low resources consumption, accounts for a large proportion of scientists and it has high labor productivity. Complex technical product performances and upgrades quickly. Economic structural adjustment and industrial upgrading make job levels and standards on the rise, increase technology. Enterprise needs large high quality of technicians to put technology prototype to specific design, and implement it. It needs large high quality technicians to maintain, monitor actual technology system or organization system. It needs large high quality technicians in service field using specifically knowledge and technology. Higher vocational education is more difficult to adapt to the new knowledge, capacity and quality requirements. So four-year vocational education is urgent. Reality environment needs higher level of vocational education involve in it. It is reported that labors in the manufacturing sector added one-year in education; the productivity would increase $17 \%$. Compared with other developed countries, professional and technical personnel in China are short of educating. Higher vocational education in undergraduate level would facilitate the adjustment of our economic structure, improve our capacity for innovation, and maintain sustained, stable and healthy economic growth.

\section{Acknowledgement}

This research work was supported by Hebei Planning
Office of Philosophy and Social Science under grant No. HB14JY064.

\section{References}

[1] 2014 national education statistics. http://www.moe.edu.cn/.

[2] http://edu.ifeng.com/news/detail_2014_04/29/36079436_0.sht $\mathrm{ml}$.

[3] Wang Zhehe. Research on the Difficulties and Countermeasures of the Transformation Development of New Local Undergraduate Colleges and Universities. China Higher Education Research, 2015(4).

[4] Luo Li, Keling Liao. Native perspective: Higher Vocational Education Development Path Choice. Economic Research Guide, 2012(13).

[5] Xiaoming Li. Industry Transformation and Upgrading and the Development of Higher Vocational Undergraduate Education: Transformation of Local Application-oriented Undergraduate to Higher Vocational Undergraduate Education as a Solution. Exploring Education Development, 2012(3).

[6] Chunlei Wang. The Transition of Local Undergraduate Universities: The Turn Point of the Formation of the Hierarchical Structure of Vocational Education. Journal of Higher Education Management, 2015(5).

[7] Jian Chen. On the Predicament and Mode Construction of Higher Vocational Undergraduate Education Development. Journal of Wuxi Institute of Technology, 2014(3).

[8] Yaming Wang, Jue Wang. Research on Current Situation, Difficult Position and Countermeasures of China's Higher Vocational Undergraduate Education. China Higher Education Research, 2014(3).

[9] Jing Guan, Jin Li. The Research Boundary and Dimensions of Modern Vocational Education System. China Higher Education Research, 2014(1).

[10] Wei Nie. The Current Situation, Problem and Transforming Paths of the Academic Community in China. China Higher Education Research, 2012(11). 